\title{
Universiteit
}

Leiden

The Netherlands

\section{Massah and Meribah re-interpreted: biblical accounts, Judith, and Josephus}

Henten, J.W. van; Castelli, S.; Troyer, K. de; Schmitz, B.; Alfaro, J.; Häberlein, M.

\section{Citation}

Henten, J. W. van, \& Castelli, S. (2020). Massah and Meribah reinterpreted: biblical accounts, Judith, and Josephus. In K. de Troyer, B. Schmitz, J. Alfaro, \& M. Häberlein (Eds.), Deuterocanonical and Cognate Literature Studies (pp. 19-48). Berlin/ Boston: De Gruyter. doi:10.1515/9783110691801-004

Version: $\quad$ Publisher's Version

License: $\quad$ Licensed under Article 25fa Copyright

Act/Law (Amendment Taverne)

Downloaded from: $\quad$ https://hdl.handle.net/1887/3238731

Note: To cite this publication please use the final published version (if applicable). 


\section{Massah and Meribah Re-interpreted: Biblical Accounts, Judith, and Josephus}

\section{Introduction}

The Massah and Meribah pericopes in the Hebrew Bible are part of a cluster of passages in which the theme of testing is prominent.All passages are set in the wilderness period of forty years, during which the Israelites journeyed from Egypt to the Promised Land. There are three parties involved in the testing: God, the people of Israel and the people's leader, who also acts as God's representative: Moses (sometimes Moses and Aaron). ${ }^{1}$ The testing motif is especially important in the short passage about the Waters of Massah and Meribah in Exodus 17:1-7, which is open to several interpretations, as retellings and allusions to the episode show. ${ }^{2}$ The Israelites' testing of God is explicit in this passage, which may also imply, like its parallel in Numbers 20, that Moses was tested as well, namely by God (Exod 17:1-7; Num 20:8-12).

The re-interpretations of the Massah and Meribah tradition, however, extend well beyond the Hebrew Bible. ${ }^{3}$ In this contribution we will discuss the re-interpretations of the Massah and Meribah episode not only in the Hebrew Bible, but also in the Septuagint and in two post-biblical writings (Judith and Josephus's Antiquities). We will focus primarily on the testing motif, but also on the issue of water shortage, notably in Judith, and on the interpretation of the miracle performed by (and on the role of) Moses, depending on which features are foregrounded in the relevant re-interpretations.

Because the testing motif is prominent in Exodus 17 and several re-interpretations, we should explain right at the start that one can approach this motif by

1 Jan Willem van Henten, The Triangle of Testing in the Wilderness (forthcoming).

2 Retellings in the Hebrew Bible include Num 20:1-13; Deut 6:16; 33:8; Ps 81:7; 95:8 -9; allusions include Ps 78:15-20, $40-41,56 ; 106: 14,32-33$.

3 Roy E. Garton, Mirages in the Desert: The Tradition-historical Development of the Story of Massah-Meribah. BZAW 492 (Berlin: De Gruyter, 2017), 2: "it is clear that the Massah and Meribah tradition did not achieve consistent formulation prior to, or even immediately after, its codification. Instead, the Massah and Meribah tradition continued to be a 'living tradition:' the imaginative reflections and appropriations of which extend well beyond the confines of the Hebrew Bible”. Cases of re-interpretation of this tradition include Wis 11:4-10; Philo, Det. 115-8; Heb 3:7-11 and Josephus (see further). 
imagining it as the figure of a triangle, with three parties (God, the Israelites and Moses) each connected with a corner of the triangle and the testing activity taking place along the sides of the triangle, in both directions. This means that we can imagine at least three forms of the testing motif:

(1) The Israelites putting God to the test (cf. Exod 17:1-7)

(2) God testing the Israelites (cf. Exod 15:22-27; 16)

(3) God testing Levi-Moses (cf. Deut 33:8) ${ }^{4}$

One side of the triangle remains inactive according to the relevant Hebrew Bible passages, but we will observe later on that re-interpretations of the Massah and Meribah episode add to the complexity of the testing motif by also focusing on the people testing its leader. We will start our survey with the relevant passages in the Hebrew Bible.

\section{Massah and Meribah in the Hebrew Bible}

The Massah and Meribah episode in Exodus (Exod 17:1-7) is situated at Rephidim (17:1) before a battle takes place against Israel's arch-enemy Amalek $(17: 8-13) .^{5}$ Further on the narrative refers to Mount Horeb (17:6), where the Israelites arrive according to Exodus $19 .{ }^{6}$ When the Israelites arrive at Rephidim after their departure from the wilderness of Sin, they are afraid that they will lack water, as they did before in the Wilderness of Shur and at Marah (Exod 15:22-26). In their despair they start to quarrel with their leader Moses (Exod 17:1-2; cf. 15:24; 16:2-3) and demand water. In the MT the Israelites address Moses with a plural phrase that implies that not only Moses was addressed: “Give us (תנו־לנו) water to drink" (Exod 17:2). ${ }^{7}$ Moses responds that they address

\footnotetext{
4 Details in van Henten, Triangle of Testing.

5 Nathan MacDonald, “Anticipations of Horeb: Exodus 17 as Inner-Biblical Commentary," in Studies on the Text and Versions of the Hebrew Bible in Honour of Robert Gordon, ed. Geoffrey Khan and Diana Lipton (Leiden: Brill, 2012), 7-19.

6 Benno Jacob, Das Buch Exodus (Stuttgart: Calwer Verlag, 1997), 1044-54, considers "on Horeb" in Exod 17:6 a gloss: according to his interpretation, the mountain of the Law would be Sinai, and not Horeb. On the other hand, for William Propp, Exodus 1-18: A New Translation with Introduction and Commentary (New York: Doubleday, 1999), 613 "on Horeb" is "a key component of the imagery of the 'Mountain of Theophany'." Actually, Propp places the very episode of Massah and Meribah at Mount Horeb. See further for Josephus's view on the location of this episode.
}

7 Most of the textual tradition of Exod 17:2 has the singular (תנה לנו) instead of the plural attested in the MT, including 4Q22 [4QpaleoExod ${ }^{\mathrm{m}}$ ], see Patrick W. Skehan, Eugene C. Ulrich, and Ju- 
the wrong person. In his view the criticism of the Israelites implies that they cast doubt about God's support of them (cf. Exod 16:7): "Why do you quarrel with me (מה־תריבון עמדי)? Why do you test the Lord (מה־תנסון את־יהוה; 17:2)?” Moses's response remains futile; the Israelites point out in plain language that their departure from Egypt would ultimately lead to their death because of the lack of water (Exod 17:3; cf. 16:3). Moses is at a loss and cries out to God because he is afraid that the Israelites will act as a mob and stone him (17:4). ${ }^{8}$ God brings deliverance through a water miracle executed by Moses (17:5-6), which is only partially explained: Moses has to take the staff with which he struck the Nile and strike a piece of rock at the Horeb, while God is standing before him. Why this gesture is effective remains unclear. The pericope ends in 17:7 with Moses's explanation of the double name of the place of the miracle: "He called the place Massah and Meribah, because the Israelites quarrelled and tested the Lord (על־ריב בני ישראל ועל נסתם את־יהוה be a flashback, because the outcome of the story is that God is clearly with the Israelites and supports them.

Within the Book of Exodus, the Massah and Meribah episode concerns a third round of testing in the wilderness, following upon the testing in the Wilderness of Shur, when the Israelites were confronted with the bitter water at Marah (Exod 15:22-27), and the testing in the wilderness of Sin (Exod 16), where the Israelites were afraid to die because of hunger (Exod 16:3; cf. 15:24). The testing motif in Exodus 17 is more complex than that in chapters 15-16, also because Moses's role as leader and intermediary between God and the people is more prominent. The text also connects the vocabulary of testing and quarrelling with the location where these activities take place. The most common vocabulary referring to testing in the Hebrew Bible concerns the verb נסה (in the pi'el; main meaning "put someone to the test") and related nouns. ${ }^{10}$ The root נסה is connect-

dith E. Sanderson, Qumran Cave 4.IV: Palaeo-Hebrew and Greek Biblical Manuscripts, DJD 9 (Oxford: Clarendon Press, 1992), 93, col. XVII, 1. 19; the Samaritan Pentateuch, the Septuagint, the Peshitta, some of the targumim, the Vulgate, and even some manuscripts of the MT; see Benjamin Kennicott, Vetus Testamentum Hebraicum, cum Variis Lectionibus ... (Oxford: Clarendon Press, 1776), 1:142; Giovanni Bernardo de Rossi, Variae Lectiones Veteris Testamenti ... (Parma: Bodoni, 1784), 1:61.

8 Cf. Num 14:10. Propp, Exodus, 605.

9 The name Massah (מסה) נסה (below), the name Meribah (מרבה) with the root ריב; both verbs occur in Exod 17:2, 7.

$10 K B L^{3} 3: 663$; Lothar Ruppert, "Das Motiv der Versuchung in vordeuteronomischer Tradition," VT 22 (1972): 55-63; Gillis Gerleman, "נסה nsh pi. versuchen,” THAT 2:69-71, 70: "prüfen, [jemanden] auf die Probe stellen". This meaning of נסה ("put someone to the test") presupposes בחן a personal object, which leads to the question "who tests whom?" Cf. the related root 
ed with an abstract noun that derives from the verb: מסה massāh "test" (Deut 4:34; 7:19; 29:2). ${ }^{11}$ In Exod 17 and a few other passages מסה Massāh functions as a geographical name with the meaning "Test, Place of Testing," as will become clear from briefly reviewing the passage. ${ }^{12}$ Likewise the name Meribah is given to this location because it was the place where the Israelites quarrelled with Moses (17:7). In Exod 17 the Israelites put God to the test by their lack of faith, which is remarkable in the light of God's deliverance during the exodus as well as the wilderness journey (Exod 12-16). It is therefore not surprising that God passes the test by providing water. ${ }^{13}$

The parallel version of the Massah and Meribah episode in Num 20:1-13 differs in several ways from Exodus 17. The name Massah is absent in Num 20, as in Ps 106:32, and is simply called "the waters of Meribah" (Num 20:13). This version also lacks the testing vocabulary but it may presuppose at least a kind of test for Moses as well as Aaron, who had to show God's holiness in front of the Israelites by performing the water miracle (Num 20:12). Moses becomes impatient because of the criticism of the people and partly disobeys God's command. He says to the people: "Listen, you rebels, shall we bring water for you out of this rock? Then Moses lifted up his hand and struck the rock twice with his staff; water came out abundantly ... (20:10 -11)." As a consequence, Moses and Aaron were not allowed to bring the Israelites into the Promised Land because they did not trust in God (לאזהאמנתם בי, 20:12). The salient point of this version is that Moses acts prematurely during the water miracle. He uses Aaron's rod and acts as saviour of the Israelites instead of God. ${ }^{14}$ Other Hebrew Bible passages referring to Massah and Meribah include Psalm 78, which provides a survey of the history of Israel and alludes to the Massah and Meribah episode (Ps 78:15-16, 20). The passage focuses on the people of Israel, who rebelled against God in the wilderness despite God's mighty deeds of deliverance and tested him by demanding food (Ps 78:18-20; cf. 78:40-41):

"test”, parallel with נסה in Ps 26:2; 95:9; 1QH 2:13-14. Other uses of the verb נסה: "tempt" and

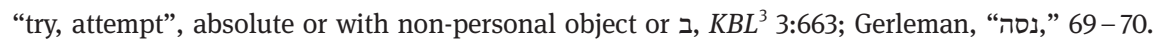
11 Gerleman, “נסה," 70. Another related abstract noun is ("test”) in Sir 36(33):1; 44:20; 1 QS 1:18; 4QDibHam ${ }^{\mathrm{a}}$ [4Q504 fragm 1-2] 5:18; 6:7.

12 See also Deut 6:16; 9:22; 33:8; Ps 95:8; Sigo Lehming, “Massa und Meriba," ZAW 73 (1961): 71-7; Gerleman, "נסה", 69. Further discussion in Elias B. Oikonomos, Peirasmoi en te Palaia Diatheke: Oroi, Keimena kai morphologike ereuna (Athens: Bibliotheke tes en Athenais Philekpaideutikes Etaireias, 1965 [Greek]); Jacob Licht, Testing in the Hebrew Scriptures and in Post-Biblical Judaism (Jerusalem: Magness Press, 1973 [Hebrew]).

13 Cornelis Houtman, Exodus, HCOT 2 (Kampen: Kok, 1996), 357; 362-3.

14 Jacob, Exodus, 491. 
(18) They tested God in their heart (וינסו־אל בלבבם)

by demanding the food they craved.

(19) They spoke against God, saying

"Can God spread a table in the wilderness?

(20) Even though he struck the rock

so that water gushed out

and torrents overflowed,

can he also give bread

or provide meat for his people?"

Moses is not even mentioned in this passage, which highlights the lack of faith of the Israelites (cf. 78:22) by the testing motif. ${ }^{15}$ Ps 95:8-11 calls upon the readers not to follow the example of their ancestors at Massah and Meribah, who had hardened their hearts and tested God, and, therefore, were not allowed to enter God's rest, i.e., the Promised Land. Ps 81:7 refers to the Massah and Meribah episode and reverses the roles of God and the people, ignoring Moses's role. Ps 106:32-33 also criticizes Moses's role as leader, together with the people. The Israelites make God angry at Meribah ${ }^{16}$ but also entice Moses to say "words that were rash." 17

The Book of Deuteronomy includes several passages with the testing theme, which may even go back to traditions that are earlier than the Exodus passages. Nevertheless, they read like flashbacks to episodes in the wilderness narrated before in Exodus and Numbers. Moses's instructions to the Israelites for the period in the Promised Land (Deut 6:4-8:20) include the commandment not to test God in the future and refers twice to the Massah and Meribah episode: "Do not put the Lord your God to the test, as you tested him at Massah לא תנסו את־יהוה 6:16).”18, אלהכם כאשר נסיתם במסה

15 Obviously the Israelites are punished because of their lack of trust (Ps 78:21-22, 31). See also 2 Esd 1:20, where God addresses the Israelites, saying "When you were thirsty, did I not split the rock so that waters flowed in abundance?" (Nonne cum sitiretis petram excidi, et fluxuerunt aquae in satietatem?).

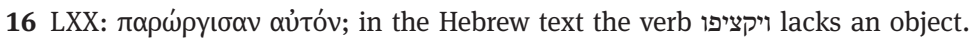

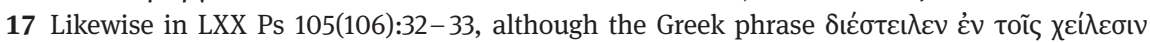

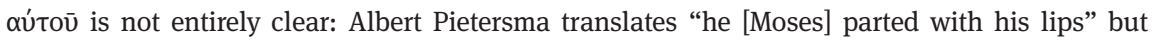
states in a note "possibly spoke rashly" (NETS). $L E H^{1}$ 1:109 gives "pronounce, makes an explicit

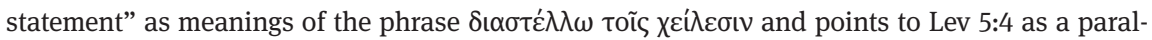
lel. The critical interpretation of Moses' words derives, perhaps, from Exod 17:4, because Moses' cry in this verse can be interpreted in various ways; see Houtman, Exodus, 363.

18 Moshe Weinfeld, Deuteronomy 1-11: A New Translation with Introduction and Commentary (New Haven: Yale University Press, 1991), 346-7. Cf. Ahaz's implementation of this commandment in Isa 7:12. 
Moses interprets the entire period of forty years in the wilderness as a period during which God put his people to the test (Deut 8:2-4, 16) ${ }^{19}$ Moses calls upon the Israelites to remain faithful to God's commandments and pass the test connected with the commandments to their own benefit because of God's continuous saving activities: “... He [God] made water flow for you from flint rock [at Massah and Meribah], and fed you in the wilderness with manna that your ancestors did not know, to humble you and test you, and in the end to do you good (8:15-16)."20

Another key passage of Deuteronomy suggests an alternative interpretation of Moses's role by implying that Moses was tested and that he passed the test by remaining faithful (Deut 33:8-11). ${ }^{21}$ This passage about the blessing of Levi focuses fully on the test of the leader and makes the triangle of testing explicit. It implies that God put Levi to the test, but the beginning of the blessing associates Moses with Levi through a reference to Massah. God is the implied subject, so God tested Levi-Moses. ${ }^{22}$ Levi is rewarded for his faithfulness, he is characterized as God's loyal one and should receive God's Thummim and Urim (33:8). The motivation for this blessing is given by references to Massah and Meribah as flashbacks. In the light of the wilderness passages in Exodus and Numbers, these flashbacks can only concern Levi's descendant Moses (Exod 2:1), although this causes some friction with these preceding passages (especially the last part of verse 8):

And of Levi he [Moses] said

Give to Levi your Thummim,

And your Urim to your loyal one (לאיש חסידך)

Whom you [God] tested at Massah (אשר נסיתו במסה),

With whom you contended at the waters of Meribah (מריבה מי־על); (Deut 33:8)

19 Cf. Num 14:22 and Ps 78:41.

20 There is some ambiguity in the testing motif here: God first creates distress for the Israelites and then brings deliverance, apparently because the Israelites passed the test; Licht, Testing, 43-7.

21 Ruppert, "Motiv," 56-8.

22 Detailed discussion in Stefan Beyerle, Der Mosesegen in Deuteronomium (Berlin: De Gruyter, 1997), 113-36. For Qumran versions of the blessing (esp. 4Q175:14-20), see Eugene C. Ulrich et al., Qumran Cave 4.IX: Deuteronomy, Joshua, Judges, Kings (DJD 14; Oxford: Clarendon Press, 1995), 61-70; Russell Fuller, "The Blessing of Levi in Deut 33, Mal 2 and Qumran," in Konsequente Traditionsgeschichte, ed. Rüdiger Bartelmus, Thomas Krüger, and Helmut Utzschneider (Fribourg: Universitätsverlag; Göttingen: Vandenhoeck \& Ruprecht, 1993), 31-44; Julie A. Duncan, “New Readings for the 'Blessing of Moses' from Qumran,” JBL 114 (1995): 273-90 (273; 280 -4; 287-8); Stefan Beyerle, "Evidence of a Polymorphic Text: Towards The Text-History of Deuteronomy 33,” DSD 5 (1998), 215-32. 
Moses formulates this blessing as a request from God, who is the implied subject of "give" (33:8). The gift of the Thummim and Urim emphasizes together with the reference to the incense and burnt offerings in verse 10 the priestly and cultic connection of the Levites. ${ }^{23}$ Levi is God's loyal one, because he was tested at Massah. ${ }^{24}$ The blessing further implies that the Levites should be blessed because Levi (or Moses in the light of other passages) passed the test at Massah and Meribah (33:8). The end of the blessing indicates that the blessing should make the Levites victorious over their opponents:

Bless, O Lord his substance,

And accept the work of his hands;

Crush the loins of his adversaries,

Of those that hate him, so that

They do not rise again. (Deut 33:11)

Deut 33:8-11 offers a remarkable interpretation of the testing motif in Exod 17 by associating Moses with Levi and legitimating Levi's tribe's priestly activities on the basis of the outcome of the test at Massah and Meribah. It also indicates the success of this tribe in dealing with adversaries, which by itself implies a role as leader or leaders of the people. We will see later on that some of the re-interpretations of the Massah and Meribah episode build on this last part of Levi’s blessing.

\section{Massah and Meribah in the Septuagint}

How does the Septuagint render the Massah and Meribah passages of the Hebrew Bible? In most cases the Septuagint remains close to the Hebrew text. An exception concerns LXX Psalm 94(95):8-9, which doesn't offer the Greek equivalent of the names Massah and Meribah, but refers to them as situations of rebellion against God and testing of God in the wilderness: "(8) do not harden your hearts as at the embittering ( $\dot{\omega} \zeta \mathcal{\varepsilon} \nu \tau \tilde{\omega} \pi \alpha \rho \alpha \pi \iota \rho \alpha \sigma \mu \tilde{\omega}) /$ like the day of trial in

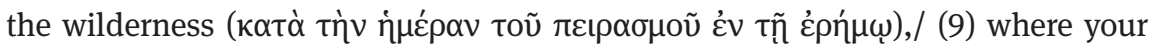

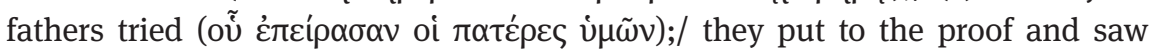
my works."

The most important re-interpretations concern the translations of Exod 17 and Deut 33:8-11. In the short story set at Rephidim in Exod 17:1-7 the Septua-

23 Beyerle, Mosesegen, 120-4.

24 Beyerle, Mosesegen, 125. 


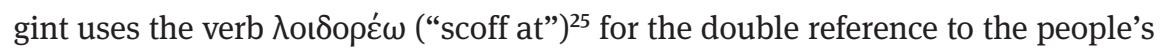
quarrel with Moses because of the lack of water (17:2). The testing motif in v. 2 is

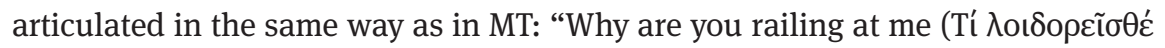

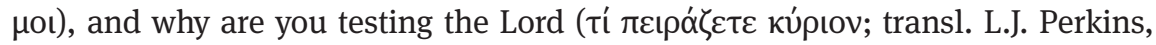
NETS)?"26 The verb yoyyú $\zeta \omega$ ("mutter, mutter against") translates the root לון that expresses the people's complaint to Moses in v. $3 .{ }^{27} \mathrm{~A}$ few details in vv. 4-6 differ from the Masoretic Text: the Septuagint interprets Hebrew את־היאר, which can

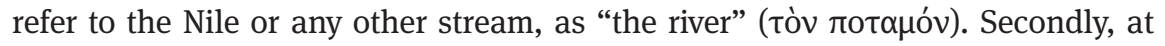
v. 6 the LXX changes the meaning of space found in the Hebrew (הנני עמד לפניך "I will be standing there in front of you") into a temporal meaning: God

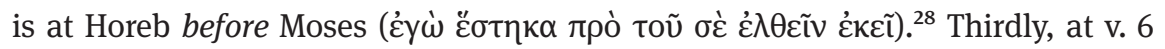
Moses performed his miracle at the rock in front of all the Israelites (Évavtíov

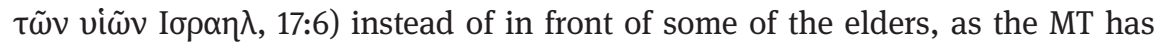
it (17:5-6) ${ }^{29}$ Fourthly, Moses's statement at the end of the pericope (17:7) provides Greek names for the symbolic double new name of the place, but their meanings remain close to the MT version, implying that the focus is here too on the people of Israel testing the Lord whether he was among them or not:

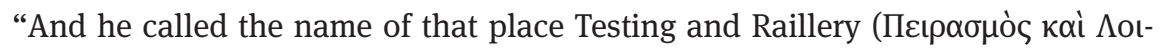

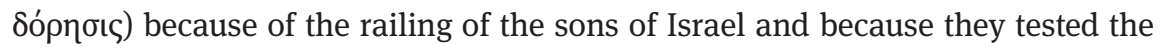

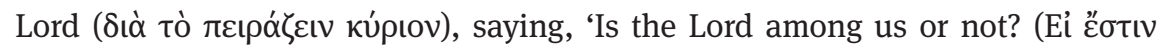

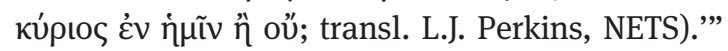

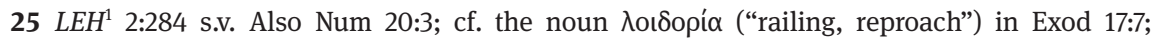
Num 20:24.

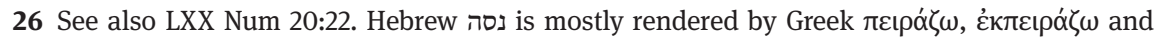

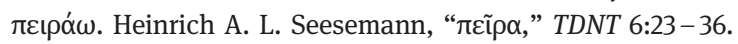

$27 L^{L E H^{1}}$ 1:92 s.v. yoyyú $\zeta \omega$; Alain Le Boulluec and Pierre Sandevoir, La Bible d'Alexandrie: L'Ex-

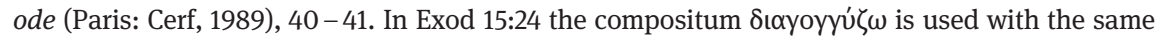
meaning.

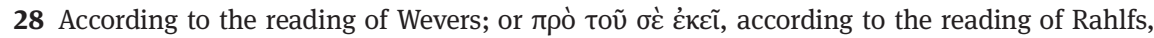
which follows Vaticanus and is closer to the Hebrew. Accordingly, Philo explains that God comes before every creature, and that ह̌ $\sigma \tau \uparrow \kappa \alpha$ indicates the unaltered stability of the divine presence (Leg. 3.4; Sacrif. 67-68; Somn. 2.221).

29 MT Exod 17:6: לעיני זקני ישראל. Jacob, Exodus, 494. 4Q22 [4QpaleoExod"m] attests זקני, matching with the Masoretic text; see Skehan, Ulrich and Sanderson, Qumran Cave 4.IV, col. XVII, 1. 19. The Peshitta introduces the concept of the "children of Israel" that seems to bring it closer to the LXX reading, but actually has a text that is similar to that of the MT: l-'ayn sabe da-bnay 'israel ("[Moses did so] at the sight of the elders of the children of Israel"), in other words, in front of the elders, as in the MT. MS London BL Add. 14.125 (with others that depend on it) reads instead of da-bnay 'israel "[at the sight of the elders] of the children of Israel" only $d$-'israel, that is, "[at the sight of the elders] of Israel." In that way, it comes closer to the Masoretic text. We are indebted to Piergiorgio Borbone (Pisa) for this reference. 
The Septuagint version of Deut 33:8-11 interprets the motif of testing differently than the Masoretic Text and sets it in a messianic and eschatological framework (cf. 33:11). ${ }^{30}$ It states explicitly that the Israelites put Levi(-Moses) to the test:

(8) And to Levi he said

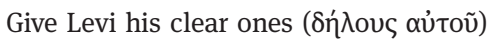

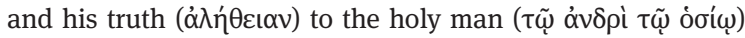

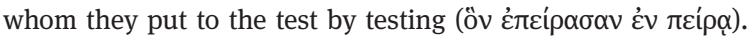

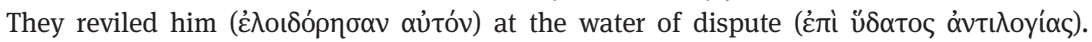

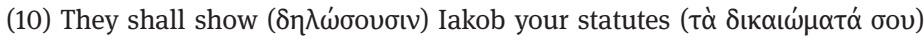

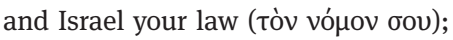

they shall place incense $\left(\theta v \mu \mu^{\alpha} \alpha \alpha\right)$ on [or: in] your wrath ${ }^{31}$

continually on your altar.

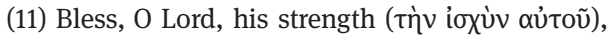

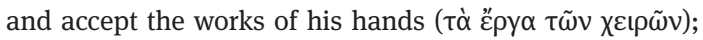

shatter the loins of his enemies that have

risen up against him,

and those that hate him, let them not rise up

(transl. Melvin K.H. Peters, NETS, slightly adapted).

We have given the translation of this passage almost in full, because it is probably alluded to in some of the re-interpretations discussed below. We only comment here on some details that are directly relevant for the re-interpretation of the passage. "His clear ones" and "his truth" concern the Septuagint rendering of the Thummim and Urim (above), the explaining devices of the high priest,

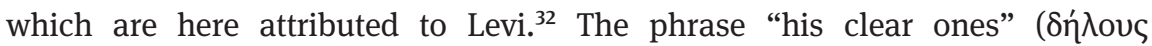
aủtoũ) may be echoed by the beginning of v. 10: "They shall show

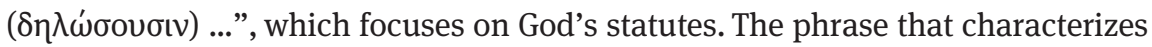
Levi as "holy man" or "holy one" is unique in the Septuagint. It highlights Levi's

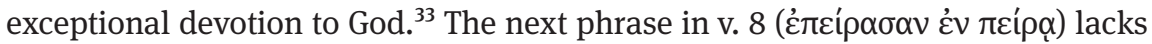

30 Beyerle, Mosesegen, 115; 118.

31 The Septuagint translator seems to have taken the Hebrew באפך ("before you") in the literal sense.

$32 L^{L E H^{1}}$ 1:100 gives "symbols of revelation, manifestation" as meaning for the substantivated plural masculine of $\delta \tilde{\eta} \lambda$ os, indicating that this is a rendering of Urim interpreted as deriving from the root "to give light" (cf. 1 Sam 28:6). See also Cécile Dogniez and Marguerite Harl, La Bible d'Alexandrie: Le Deuteronome (Paris: Cerf, 1992), 346; John William Wevers, Notes on the Greek Text of Deuteronomy, SCS 39 (Atlanta: Scholars Press, 1995), 543; Beyerle, Mosesegen, $120-2$.

33 Cf. Ps 31(32):6 LXX, $L E H^{1}$ 2:340. 
the geographical reference to Massah of the Masoretic Text, which may have been misunderstood. The translator may have interpreted the Hebrew phrase as a figura etymologica, in which case the repetitive lexem - $\pi \varepsilon i$ pputs emphasis on the fact that Levi was tested. ${ }^{34}$ Likewise the Hebrew words

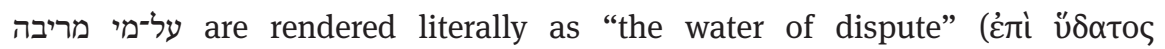

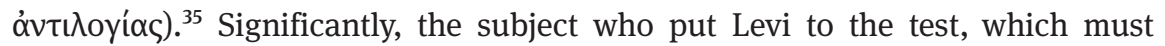
have been God by implication in the Masoretic Text, is changed into the plural. The context implies (cf. the last line of v. 8) that the Israelites put Levi to the test, which makes the testing motif more complex in the explicit Septuagint passages about the Massah and Meribah episode. ${ }^{36}$ The next section will deal with the Judith story, which doesn't mention Massah and Meribah, but alludes to it, with a focus on the water shortage and the testing motif.

\section{Allusions to Massah and Meribah in Judith ${ }^{37}$}

A coherent part of the Judith story (chapters $7-15)^{38}$ seems to build on the Massah and Meribah episode as narrated in Exodus 17 as well as on the blessing of Levi in Deut 33:8-11, one of its re-interpretations. This section of the story is set in a timeframe of forty days, which triggers associations with Israel's period in the wilderness. The point of departure forms a critical situation because of a water shortage, which reminds one of Israel's wilderness episodes at Marah (Exod 15:22-26) and Massah and Meribah (Exod 17:1-7). In Judith, the Assyrian commander Holofernes causes a lack of water for the inhabitants of Judith's hometown Bethulia, because he follows the advice of the generals of the surrounding nations, captures the springs of the city, and sets guards of soldiers over them $(7: 6-7,12,17,20-21)$. His strategy is that Bethulia would surrender to him out of despair. The situation without water for the Bethulians is rather analogous to that of the Israelites in the wilderness after the exodus. Bethulia's

34 For the figura etymologica of a finite Hebrew verb followed by a noun from the same stem, see Emil Kautzsch, Gesenius' Hebrew Grammar (Oxford: Clarendon Press, 1982), 366-7.

35 Cf. Ps 94(95):8-9 LXX (above) and see also Ps 80(81):8 LXX.

36 Dogniez and Harl, Deuteronome, 347. $L E H^{1}$ 2:364 s.v. $\pi \varepsilon i ̃ \rho \alpha$ gives "temptation" as meaning of $\pi \varepsilon i \tilde{\rho} \alpha$ for this passage.

37 This section is based on a condensed and revised version of Jan Willem van Henten, "Judith as Alternative Leader: A Reading of Judith 7-13," in A Feminist Companion to Esther - Judith Susanna, ed. Athalya Brenner (Sheffield: Sheffield Academic Press, 1995), 224-52. See also Deborah Levine Gera, Judith, CEJL (Berlin: De Gruyter, 2013), 244; Barbara Schmitz and Helmut Engel, Judit: Übersetzt und ausgelegt, HThKAT (Freiburg im Breisgau: Herder, 2014), 251.

38 For introductory matters see Gera, Judith, 3-109; Schmitz and Engel, Judit, 37-69. 
inhabitants complain so much that their leaders decide to deliver the city in case God would not rescue them in the next five days (7:30). This implies that the leaders put God to the test as the Israelites did in the wilderness (above). Judith responds to the little faith of the elders and explains that God was testing the people and its leaders through the water shortage (Jdt 8:12, 25-27), which echoes the testing motif in the Marah episode (Exod 15:22-26). It is at the same time connected with the Massah and Meribah episode because Judith's criticism of the elders reminds one of Moses's call in Deut 6:16: "Do not put the Lord your God to the test, as you tested him at Massah." ${ }^{39}$ The water motif in Judith is expanded and broadened to a drinking motif (drinking to survive versus drinking leading to death), which culminates in Holofernes's failed attempt to persuade Judith to have sex with him. He dies in stupor after the drinking-bout (12:10) that he organizes in order to seduce Judith (12:1-13:2). ${ }^{40}$

The chronological framework that starts with Holofernes's capture of the springs (chapter 7) and ends with Judith's return to Bethulia with the head of Holofernes in her knapsack in the night of the fortieth day and the triumph over the Assyrian army with its decapitated commander (13:10 - 15:7) covers exactly forty days. ${ }^{41}$ Forty is a symbolic number in various contexts in the Hebrew Bible, but the combination with the water shortage and the testing motif makes the association with the wilderness period of forty years rather obvious (cf. Exod 16:35; Ps 95:10). ${ }^{42}$ The schedule of forty days starts with a chronological marker in 7:1 with "on the next day," taken up again in 7:2: "So all their warriors [the Assyrian soldiers of Holofernes] marched off that day." On the second day, Holofernes inspects the approaches to Bethulia and decides to cut the Jews off from their water supply (7:6-7). After a siege of thirty-four days (7:20), i.e. on day thirty-five, the inhabitants urge the elders to surrender Bethulia, but the elders decide to wait for five more days in case God would rescue the people. If not, they would surrender the town (7:30 - 31). The last five days are described in detail in Judith 8:1-15:7: Judith responds to the decision of the elders (chapter 8) and

39 Cf. George W.E. Nickelsburg, "Stories of Biblical and Early Post-Biblical Times," in Jewish Writings of the Second Temple Period: Apocrypha, Pseudepigrapha, Qumran Sectarian Writings, Philo, Josephus, ed. Michael Stone, CRINT II/2 (Assen: Van Gorcum; Philadelphia: Fortress Press, 1984), 33-87, 48: "The citizens of Bethulia and Judith exemplify respectively those who fail and those who pass the test".

40 The drinking motif occurs in Jdt 12:10, 11, 13, 17-20 and 13:1-2. See also also 8:9, 30 - 31; 11:12; $12: 1,7$.

41 Erich Zenger, Das Buch Judith, JSHRZ I.6 (Gütersloh: Gütersloher Verlagshaus, 1981), 435; Gera, Judith, 235. Cf. Jdt 8:4: Judith is a widow for three years and four months (=40 months). 42 Van Henten, “Alternative Leader," 229-30; Schmitz and Engel, Judit, 373. 
leaves Bethulia after a prayer in the evening (chapter 9), at the beginning of the 36th day. She stays three days in Holofernes's camp (12:7; days 36 to 38). The drinking-bout takes place on the fourth day in the camp (12:10) and Holofernes dies during the night following that day. Judith and her maid return to Bethulia with Holofernes's head during that very night (13:11-20; night of day 40). On day 40 the Bethulians and fellow-Israelites defeat the Assyrians (14:11-15:7).

Several details in the Judith story support the interconnection between Judith 7-15 and the wilderness episode at Massah and Meribah and they also imply that the role of the leader becomes more complex than in Exodus 17. The suffering Israelites of Bethulia lack faith and blame God for their distress, and put God in this way to the test as the Israelites do at Massah and Meribah: "For now we have no one to help us; God has sold us into their hands; to be strewn before them in thirst and exhaustion" (7:25; cf. Exod 17:2-3). A few lines further they blame their leaders for not surrendering to the Assyrians, which echoes complaints of Israel in the wilderness, which regrets having left Egypt: "For it would be better for us to be captured by them. We shall indeed become slaves, but our lives will be spared, and we shall not witness our little ones dying before our eyes, and our wives and children drawing their last breath" (7:27; cf. Exod 17:3: "Why did you [Moses] bring us out of Egypt to kill us and our children and livestock with thirst?”).

Judith's speech to the elders in Judith 8:11-34 focuses again on this cluster of motifs. Judith challenges the response of the people and the elders to the shortage of water. She interprets the situation of the lack of water as a test (Jdt 8:12, 25-26). First she says that the elders were wrong to put God to the test (cf. Exod 17:3), because humans cannot claim God's position and cannot know his deci-

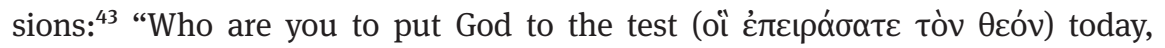
and to set yourselves up in the place of God in human affairs? You are scrutiniz-

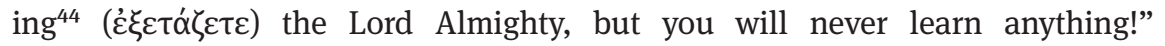
(8:12-13). Judith seems to compare here the attitude of her fellow-Israelites to that of the Israelites at Massah and Meribah, who put God to the test in order to find out whether he would help them or not (Exod 17:1-7, above). Further on in her speech to the elders she returns to the testing motif by reversing the roles of testing. She points to the possibility that instead of the people testing God, God was testing the people in this situation without water, which reminds one of God's testing of the people at Marah (Exod 15:25-26, above). She supports this interpretation of the situation by pointing to analogous situations of the

43 Licht, Testing, 57-8; Gera, Judith, 277-8; Schmitz and Engel, Judit, 251-4. 44 With Gera, Judith, 212; 277. NRSV: "putting to the test". 
people's ancestors. Since these ancestors are mentioned by name, the implication seems to be that the Marah and Massah and Meribah episodes are clustered with the testing of individual ancestors and re-interpreted in this way:

(25) In spite of everything let us give thanks to the Lord our God, who is putting us [Judith

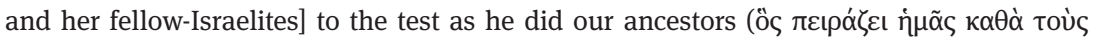
$\pi \alpha \tau \dot{\varepsilon} \rho \alpha \varsigma \dot{\eta} \mu \tilde{\omega} v) .^{45}$ (26) Remember what he did with Abraham, and how he tested Isaac

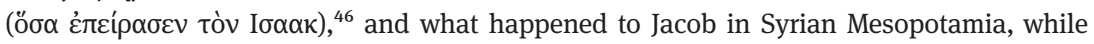
he was tending the sheep of Laban, his mother's brother (8:25-26; emphasis ours).

Judith is grateful for God putting her people to the test, because she knows the traditions from Scripture and therefore knows what the implied outcome of the testing will be. ${ }^{47}$ All three ancestors mentioned were put to the test and remained faithful to God, as the episodes alluded to imply (see Genesis 22 and 29-31). ${ }^{48}$ The ancestors mentioned, therefore, rejoiced in the support of God. The implication of the analogy between the ancestors and the Bethulians is obvious: if the Bethulians would remain faithful to God, he would certainly bring deliverance in time. ${ }^{49}$ Judith's speech, therefore, implies that the policy of the leaders is totally wrong. But because the elders are bound by their oath to surrender the city after five days (7:30; 8:30, above), Judith decides not to wait and pray, as the elders suggest, but to go on a mission that would lead to the divine deliverance of the Bethulians within the period of five days set by her leaders $(7: 30-31 ; 8: 30$, 33): "within the days after which you have promised to surrender the town to our enemies, the Lord will deliver Israel by my hand" (8:33). This implies that Judith takes responsibility for the fate of Bethulia on her own and submits herself to God's test as an alternative leader.

That the implication of Judith's audacious speech to the elders is indeed that she puts herself to the test in the substitute position of alternative leader makes sense: the elders had put God to the test with their lack of faith and were bound to their oath. If this interpretation of the testing motif in Judith is plausible, that would mean that the triangle of testing becomes more complex in Judith and focuses not only on the people but also on its leaders: (1) God is tested by the peo-

45 Cf. Exod 15:25-26 and As. Mos. 9:4.

46 Cf. 4 Macc 7:14; 13:12; 16:20; Carey A. Moore, Judith, AB 40 (Garden City, NY: Doubleday, 1985), 183; James L. Kugel, The Bible as it Was (Cambridge: Harvard University Press, 1999), 170 -7. 47 Gera, Judith, 285, comments that testing, chastisement and correction are signs of God's favor, as Deut 8:5; Ps 26:2; 94:12 and Wis 3:1-7 imply.

48 Gen 22:1 explicitly refers to the testing of Abraham. See also Sir 44:19-20; 1 Macc 2:52; 4 Macc 16:18-20.

49 Gera, Judith, $285-6$. 
ple as well as by its leaders, and (2) God tests the people as well as its leaders. Moreover, the role of the leaders is split, the elders have vowed their oath, and Judith has to take over so that the test of the leaders will be successful. It is true that the author of Judith does not state explicitly that Judith is tested, but we would like to argue that the text of Judith gives us several hints that she is tested. The clearest hints are an allusion to Exod 17:7 in Jdt 13:11 and allusions to the blessing of Levi in Deut 33:8-11 in Jdt 9:1, 9 and 13:4, 7, which imply an analogy between Judith and Levi.

As we have seen, the Massah and Meribah episode in Exod 17:1-7 ends with a short flashback: "He [Moses] called the place Massah and Meribah, because the Israelites quarrelled and tested the Lord, saying: 'Is the Lord among us or not?" (17:7). The brief question at the end of verse 7 "Is the Lord among us or

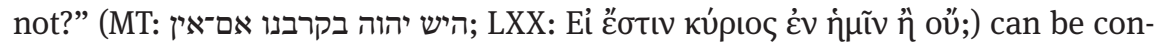
nected with the situation in Judith 7-8 and the theme of testing through water shortage. The question is answered in a negative way by the Bethulians in Jdt 7:25: "For now we have no one to help us; God has sold us into their hands ...," i.e. into the hands of the Assyrians. Strikingly, Judith herself alludes to the question of Exod 17:7, yet she answers it in an affirmative way after she has fulfilled her mission and is approaching Bethulia again (Jdt 13:10-11): "From a distance Judith called to the sentries at the gates, 'Open, open the

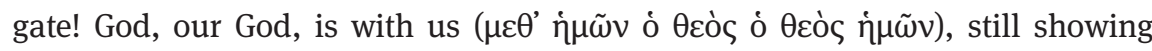
his power in Israel and his strength against our enemies, as he has done today!' (13:11; cf. 9:4, 14). ${ }^{50}$ Judith's pointing to God's power (ioxúc) and strength (кро́тос) ${ }^{51}$ against Israel's enemies in this call echoes the references to God's mighty deeds in support of Israel in the wilderness passages connected with the testing motif, but it also reflects a paradox, as Barbara Schmitz has shown: The deliverance is, as a matter of fact, not brought about by God but by Judith herself. ${ }^{52}$ Judith not only passes the test with flying colours but also

50 Because of the analogous context the allusion to Exod 17:7 is plausible, but it is obvious that phrases like "God is with us" also occur elsewhere in the Bible; see, e.g., Gen 26:3; Exod 3:12 and Judg 6:12. The closest parallel to Jdt 13:11 is found in 2 Chr 32:8 LXX about the siege of Jerusalem

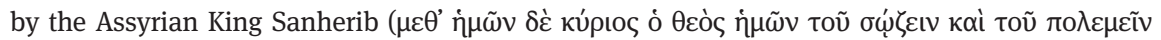

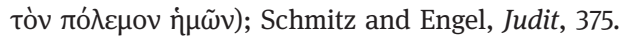

51 "Strength" only belongs to God according to Judith (9:8-9, 11, 14; 11:22).

52 Barbara Schmitz, "Gott als Figur in deuterokanonischer Literatur," in Gott als Figur. Narratologische Analysen biblischer Texte und ihrer Adaptionen, ed. Ute E. Eisen and Ilse Müllner, HBS 82 (Freiburg im Breisgau: Herder, 2016), 217-37. Judith also explains that God has struck Holofernes down by her hand (13:14-15; cf. 8:33;16:5), but the description of the deed and the proof she shows - Holofernes's head and his canopy - imply that she did it. The praise of the high priest Joaqim and the elders confirms this: "You have done all this with your own hand; you 
brings deliverance on behalf of God. The reference to God's power and strength against Israel's enemies connects with other passages in Judith about Judith's own strength.

The correspondences between Exodus 17:1-7 and the Judith narrative in chapters 7-15 discussed so far can be summarized as follows:

1. point of departure, no water

2. the people [Israelites/Bethulians] ${ }^{53}$ complain (complaint to leaders [Moses/Uzziah, elders]: give us water; it is better to be a slave [in Egypt] than to die with [women], children [and cattle] 3. response of leader[-s]

Exod 17:1

Exod 17:2-3

Jdt $7: 1-22$

Jdt $7: 23-29$

Exod 17:2-3

Jdt $7: 26-27$

Exod 17:2

(testing motif: [Moses asks the people 'Why do you Exod 17:2 test the Lord?' Judith criticizes the elders, who put God to the test])

4. leader [Moses/Judith] calls upon God

5. leader leaves for action to bring salvation

Exod 17:4

Exod 17:4-6

Exod 17:6

6. God supports leader at decisive act

[Moses strikes the rock; Judith chops off Holofernes's head]

7. conclusion: "God is with us"

Exod 17:6

Exod 17:7
Jdt $7: 30-32 ; 8$

Jdt $8: 12,25-26$

Jdt 9

Jdt $10-13^{54}$

Jdt $13: 3-10$

Jdt 13:4-8

Jdt13:11-15:13

Judith also connects her mission with the blessing of Levi in Deut 33:8-11, which refers to the testing of Levi-Moses as leader (see above). The beginning of her prayer in chapter 9 connects her mission with two ancestors, Simeon and Levi, and suggests analogies between their deeds and Judith's plan. Simeon is explicitly mentioned in Jdt 9:2-3 in connection with the revenge of Dinah in Gen 34, executed by Simeon and Levi. Levi may be alluded to in the reference to the setting of Judith's prayer at the time of the evening incense offering in

have done great good to Israel, and God is well pleased with it. May the Almighty Lord bless you forever!” (15:10).

53 The square brackets indicate details that are given by only one of the two narratives.

54 A striking detail in Exod 17:4 is Moses's fear that the people will stone him. Stoning is the usual punishment for adultery (e.g. Deut 22:22-27) and adultery is a motif in the passages about Judith's seduction of Holofernes (Jdt 10:21-13:2), although nothing intimate happens between the two (cf. Jdt 13:16). Betsy Merideth, "Desire and Danger: The Drama of Betrayal in Judges and Judith," in Anti-Covenant: Counter-Reading Women's Lives in the Hebrew Bible, ed. Mieke Bal, JSOTSup 81 (Sheffield: Almond Press, 1989), 63-78; Jan Willem van Henten, "Words and Deeds: Seduction and Power in Judith and Deathproof," in A Feminist Companion to Tobit and Judith. FCB Second Series, ed. Athalya Brenner-Idan and Helen Efthimiadis-Keith (London: Bloomsbury T\&T Clark, 2015), 226-41. 


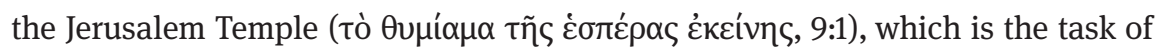
the Levites according to Levi’s blessing in Deut 33 (MT Deut 33:10: ישימו קטורה

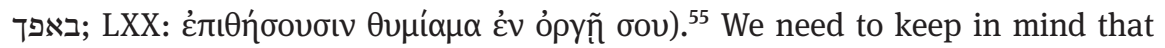
Judith descends from Levi according to her genealogy in Jdt 8:1 (through Levi's third son Merari, Gen 46:11). ${ }^{56}$ If the story of Judith builds on Levi's blessing, this may imply that Judith as a descendant of Levi can participate in the blessing.

Judith seems to allude in chapter 9 to the blessing of Levi when she prays to God to give her strength at this crucial period of water shortage and to enable what she plans to do. She prays again at the decisive moment when Holofernes lies dead-drunk on his bed after the drinking-bout (chapter 13). Key phrases in

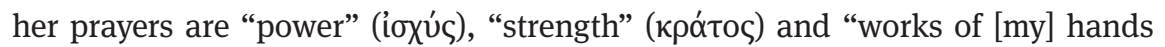

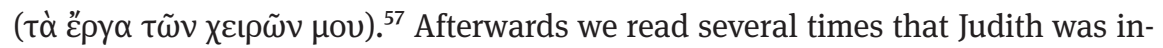
deed blessed because of her achievement (below). In Jdt 9:9 she prays: "Give to

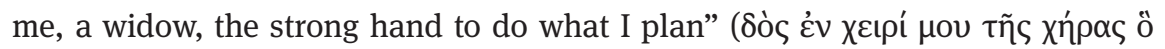

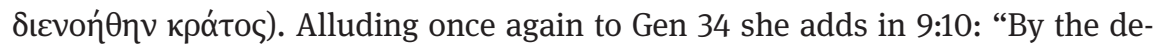
ceit of my lips strike the slave with the prince and the prince with his servant;

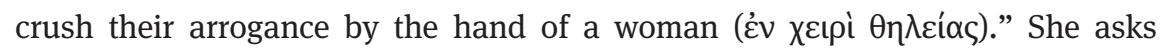
God: "Break their strength by your might, and bring down their power in your

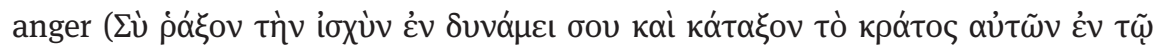

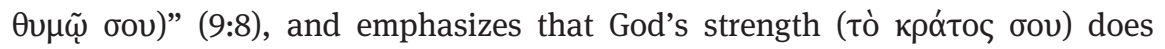

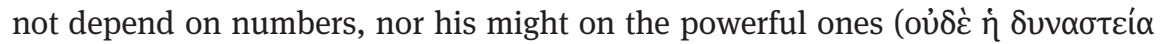

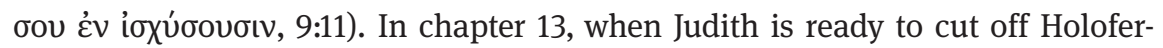
nes's head, there is another brief prayer during which Judith prays for strength:

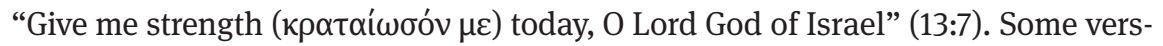
es earlier she asks if God would look in this hour favourably on the work of her

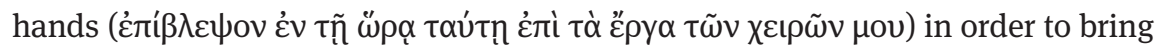
glory to Jerusalem (13:4). There is another reference to Judith's strength in the verse that describes how she chops off the head of Holofernes: "Then she struck

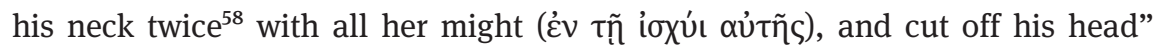
(13:8).

55 Re-interpretation in LXX: "they shall place incense in your wrath” (NETS, with “... on your wrath" and "... when you are angry" as alternative translations).

56 Van Henten, "Judith,” 247-50; Gera, Judith, 255-8; Helen Efthimiadis-Keith, "Genealogy, Retribution and Identity: Re-interpreting the Case of Suffering in the Book of Judith," OTE 27 (2014): $860-78,870-1$.

57 Cf. Jdt 5:3, 23 about the power of the Israelites, and 11:7 about Holofernes's power, which is ironical.

58 Cf. Moses, who strikes the rock twice with his staff according to Num 20:11. 
The passages listed above may build on Moses's blessing of Levi in Deut 33:8-11, which points to a special position for the Levites within Israel owing to God's support because of their faithfulness to him. Moreover, the blessing includes most of the key phrases that are prominent in Judith's prayers. Deut 33:11 reads: "Bless, O Lord, his [Levi's] substance, and accept the work of his hands

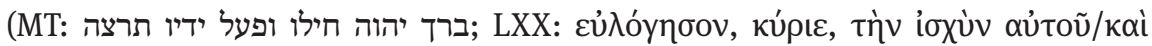

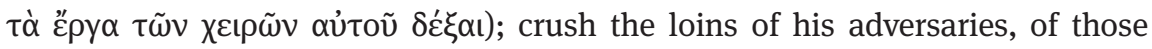
that hate him, so that they do not rise again" (33:11). If we read Judith's prayers through the lens of the blessing, she would call upon God to be blessed like Levi. The outcome of her master plan implies that Judith was blessed indeed and succeeded in eliminating the commander of the enemy, which anticipated the victory of the Jews, as chapters 14-15 narrate. In response to Judith's counsel that explains what she has done to the Bethulians (13:12-17), Uzziah addresses Judith as being blessed by God:

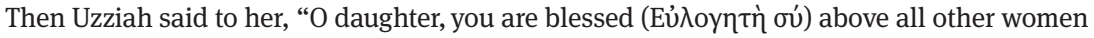
on earth; and blessed be the Lord God, who created the heavens and the earth, who has guided you to cut off the head of the leader of our enemies" (13:18)..$^{59}$

The Ammonite Achior, who got to know Holofernes, as chapter 5 describes, is called to confirm that the head taken by Judith is indeed Holofernes's head $(14: 6-7)$. When he sees it, he falls on his face and also blesses Judith: "Blessed

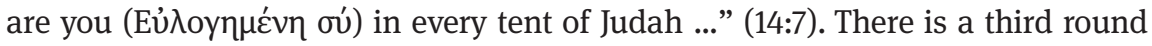
of blessing when the high priest Joakim and the elders come from Jerusalem to celebrate the victory and bless Judith (15:8 - 14). They bless her collectively (15:9)

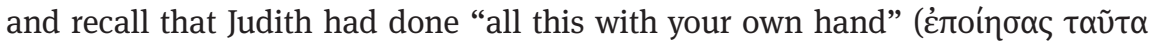

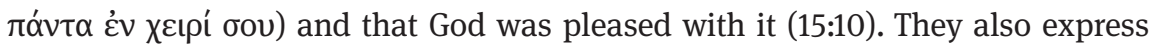

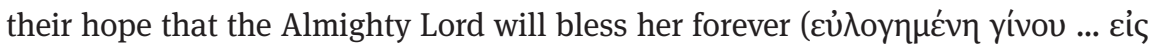

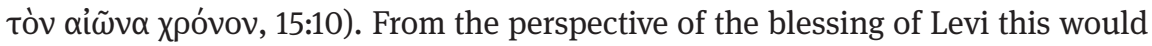
imply that the high priest and the elders state that Judith as a daughter of Levi was blessed by God through the works of her hands and that they wish that God

59 Other possible interconnections of Judith and Deut 33:8-11 may be Judith's extraordinary piety (e.g. Jdt 8:5, 8, 31) and Levi being God's “loyal one” (Deut 33:8), and Judith's announcement that she will speak reliable words to Holofernes (’’ń $\mu \alpha \tau \alpha \dot{\alpha} \lambda \eta \theta \varepsilon \dot{\alpha} \alpha$, 10:13; cf. 10:16 and

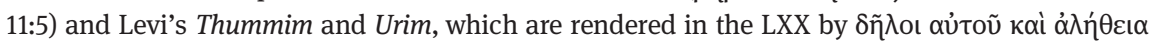

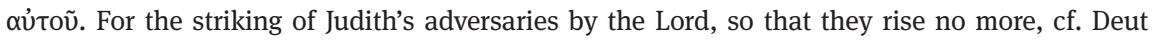

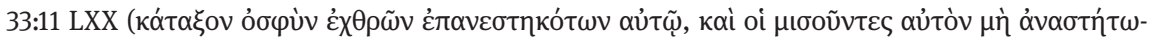

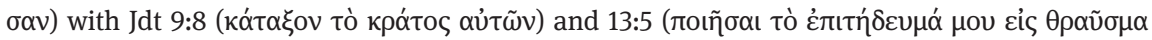

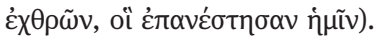


will bless her forever this way. The passage ends with all the women of Israel blessing Judith and starting a dance in order to celebrate the victory (15:12-13).

Our final section concerns the explicit re-interpretation of the Massah and Meribah episode in Josephus, who downplays the testing motif but elaborates other aspects.

\section{Massah and Meribah in Josephus (Ant. 3.33-38)}

Although the biblical text at the time of Josephus was more fluid than it is now, ${ }^{60}$ we may safely assume that Josephus knew the account of the water from the rock in both the main redactions of Exod 17 and Num 20. Josephus clearly opts for the account of Exodus rather than for that of Numbers: in his narrative, like in Exodus, Moses is alone with the people, he does not perform together with Aaron (vs Num 20:2); he strikes the rock once and not twice (vs Num 20:11); and the episode is placed at Rephidim and not in Kadesh (vs Num 20:1). The more plausible reason as to why Josephus chooses for the account of Exodus is that in Numbers Moses is more negatively portrayed than in Exodus, and Moses's role as leader is questioned by the very decision of God of not letting him bring the people into the Promised Land (Num 20:12; see above).$^{61}$ While the episode of the "waters of Meribah" (Num 20:13) is strongly biased against Moses, Josephus, according to his usual trend, enhances Moses's role and image, omitting or re-shaping the biblical elements that might question the primacy and outstanding qualities of the legislator. Hence, Josephus prefers to draw from the account of Exodus, where Moses's role is central. Moreover, in the Exodus account specifically, Josephus sets the episode at Rephidim (which he spells as 'P $\alpha \varphi ı \delta \varepsilon^{\prime} v$ ) and does not mention Horeb. Josephus works in this way as an exegete, solving a puzzling

60 E.g., Sidnie White Crawford, Rewriting Scripture in Second Temple Time (Grand Rapids, MI: Eerdmans, 2008). George J. Brooke, “The Rewritten Law, Prophets, and Psalms: Issues for Understanding the Text of the Bible," in The Bible as Book: The Hebrew Bible and the Judaean Desert Discoveries, ed. Edward D. Herbert and Emanuel Tov (London: British Library and Oak Knoll Press, 2002), 31-40. Casey Elledge, "Rewriting the Sacred: Some Problems of Textual Authority in Light of the Rewritten Scripture from Qumran," in Jewish and Christian Scripture: The Function of "Canonical" and "Non-canonical" Religious Texts, ed. James Charlesworth and Lee M. Mc Donald (London: T\&T Clark, 2010), 87-103.

61 See also Erkki Koskenniemi, The Old Testament Miracle-Workers in Early Judaism, WUNT 206 (Tübingen: Mohr Siebeck, 2005), 243. The Massah and Meribah tradition in Josephus is only marginally considered in the large-scope chapter of Paul Spilsbury, "Exodus in Josephus," in The Book of Exodus: Composition, Reception and Interpretation, ed. Thomas B. Dozeman, Craig A. Evans and Joel N. Lohr, VTSup 164 (Leiden and Boston: Brill, 2014), $465-84$ (478). 
issue of the Exodus tradition, as we have seen above. Both the choice for one biblical account rather than a parallel one and the fact of solving problematic biblical issues are standard exegetical practices in Josephus. ${ }^{62}$

Moreover, whereas in the biblical account God instructs Moses, who simply executes God's commands, Josephus turns Moses into the main actor, who is proactive on behalf of his people. That is also a trend in Josephus's biblical narrative. In the account of the water of Marah, for example, Moses shows the highest sympathy for the distress of women supplicating him on behalf of their infants, and husbands on behalf of the women. In that occasion, he not only (and vaguely) "cries out to the Lord," as in Exod 15:25, but proactively asks God for the correct solution, that is to make the water drinkable (Ant. 3.5-6). Likewise, in the episode of the water from the rock, Moses does not cry to God because the people are about to stone him, as in Exod 17:4, which implies that he was moved by fear for his life; rather, in Josephus Moses turns to prayer to God, and openly urges God to grant the people the gift of water so that its gratitude for the nourishment previously received from God would not be in vain because of the present distress (Ant. 3.34). In other words, in Josephus's account of Exodus 17, Moses is moved by his deep concern for his people and the Israelites' lack of gratitude to God, rather than by an egoistic fear for his own safety. The same trend to make Moses's intentions appear more noble than in Exodus is openly displayed in Ant. 3.21, on the Elim episode. ${ }^{63}$

We have seen that the testing motif is one of the key elements in the biblical account of Exod 15-17. The motif of testing, however, is omitted by Josephus both for Exod 17 (Ant. 3.33-38) and for the episode of the waters of Marah in Exod 15:22-26 (Ant. 3.1-8). In the latter episode, the people run to Moses to contrive some means of deliverance, not to challenge him or God (Ant. 3.6). In both episodes, God is not openly said to test the Israelites, and the Israelites do not test God either, as they do in Exodus 17 and Numbers 20. While both biblical ver-

62 Some examples are found in Michael Avioz, Josephus' Interpretation of the Book of Samuel, LSTS 86 (New York: Bloomsbury, 2015), 108-9, 164, 168, 176-82.

63 In Josephus's account (Ant. 3.21) Moses is afraid "not so much for his own safety ... but for them [the Israelites], lest through the stones that they were casting upon him they be thought to pass sentence against God”. This translation of Josephus's text, as the following, are by Louis H. Feldman. Judean Antiquities 1-4: Translation and Commentary, FJTC 3 (Leiden: Brill, 2000). Examples of Josephus's tendency to enhance Moses's character can be found in Louis H. Feldman, “Josephus' Portrait of Moses,” JQR 82.1 (1991-1992): 285-328; 83.2 (1992): 7-50; 83.3 (1993): 301-30; Louis H. Feldman, Josephus's Interpretation of the Bible (Berkeley: University of California Press, 1998), 374-442. See also Paul Spilsbury, The Image of the Jew in Flavius Josephus' Paraphrase of the Bible, TSAJ 69 (Tübingen: Mohr-Siebeck, 1998), 94-111. Spilsbury, "Exodus in Josephus," 467-72. 
sions of the Massah and Meribah tradition end the account with recalling the origin of the name of the place where the event occurs (Exod 17:7; Num 20:13), Josephus omits the name issue altogether. This omission is not due to Josephus's attempt to depict the people as more positive than in the biblical narrative. In fact, in the accounts on the waters of Marah (Ant. 3.1-8) and of Elim (Exod 15:27; Ant. 3.9-25) Josephus expands the biblical account and presents the people in a more negative way than in Exodus. At Marah, Moses needs to deal with a "rabble" (óx $\lambda$ os) of women and children who undermine the courage of men (Ant. 3.5-6); at Elim the people, focusing on its present troubles, harbours anger against Moses and presses forward to stone him (Ant. 3.12), just as they do upon the return of the spies from Canaan (Ant. 3.307). The historian, therefore, does not seem to have a problem in providing an unfavourable portrait of the Israelites, or their quarrelling with Moses. Yet, he does avoid giving hints at negative points concerning Moses. Accordingly, instead of closing the narrative of Exod 17 with the negative reference to the biblical "Testing and Quarreling," he closes the episode with a happy end, that enhances Moses's character and would please both his Jewish and non-Jewish audience: overwhelmed by the astonishing miracle of the water from the rock, the people shows its admiration

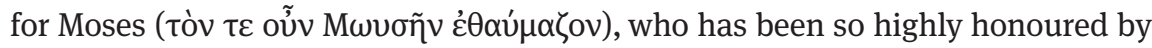

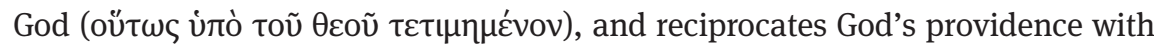
sacrifices (Ant. 3.38). ${ }^{64}$ Moreover, Josephus had already extensively elaborated on the "quarrelling" of the Israelites with Moses in the Elim episode: in leaving out the topic of testing from his account of Exodus 17, he may also have been motivated by a need of variation.

In fact, the topics of quarrelling and testing - notably, of the Israelites quarrelling with Moses and of God testing the Israelites - are made explicit in Josephus's expanded episode of Elim (Ant. 3.9-25). In the biblical account (Exod 15:27), the short description of Elim is positive: the Israelites camp there in a lush oasis of twelve springs and seventy palms.$^{65}$ However, no more detail is provided by the biblical passage on Elim, and in the following verse (Exod 16:1) the people already sets out from there and travels to the wilderness of Sin. Unlike the biblical narrative and other Hellenistic traditions that describe Elim as a locus

64 Feldman, Judean Antiquities 1-4, 241, ad loc., translates with "they also began to admire Moyses." The imperfect, however, does not imply the beginning of an action, but the fact that the action is on-going in the past. We prefer therefore to translate $\varepsilon \theta \alpha u ́ \mu \alpha \zeta o v$ with "showed admiration for."

65 In Num 33:9 Elim is likewise briefly and positively described. 
amoenus, ${ }^{66}$ Josephus depicts it as a climax of disappointment. In that way, he prepares his audience for the motifs of quarrelling and testing, which he clusters in this episode, while Exodus spreads them between Exod 15 and Exod 17. In Josephus, the Israelites are quarrelling with Moses - only indirectly with God and God tests the Israelites. The Israelites harbour anger against Moses ( $\delta$ 'ỏ $\rho y \tilde{n} \varsigma$

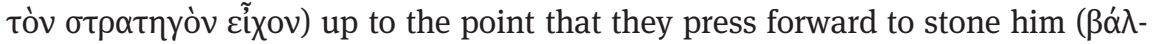

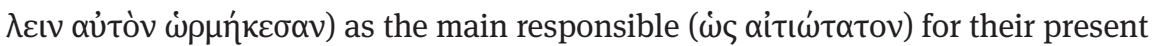
misfortune (Ant. 3.12). They complain loudly and hold the stones in their hands

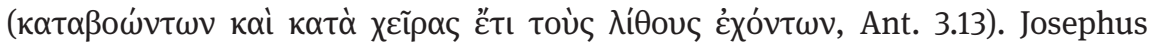
uses a speech by Moses to address the biblical motif of testing, focusing on God's testing of the Israelites. ${ }^{67}$ Moses suggests that God (Ant. 3.15; 3.19) "was

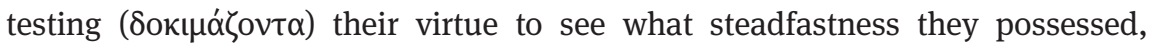
and what memory of past events they retained, whether they would recall those events because of the sufferings at their feet, and was training them (yupvá(દı

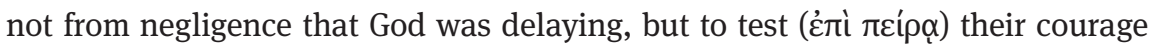

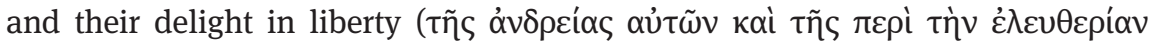

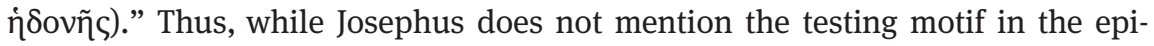
sode of the water from the rock, at Elim God is openly said to test the Israelites. On the other hand, in Josephus Moses does not need a test.

Josephus's version of the Massah and Meribah tradition is interesting also from the text-critical point of view, since it provides some hints of Josephus's source. The fact that in Josephus's account the Israelites address only Moses like in most of the tradition of Exod 17:2 against the Masoretic text - does not specifically indicate the text used by Josephus: in fact, he may use the singular simply to enhance once more Moses's role. However, another passage is more significant in this respect. At Ant. 3.36-38 Josephus has the miracle occurring not in front of the elders of Israel only, like the Hebrew Bible (Exod 17:6), but

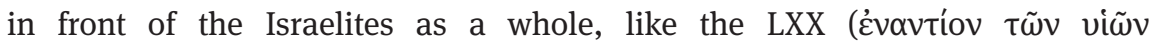

66 See Philo, Mos. 1.188-190, and especially Ezek. Trag. vv. 243-69. For the latter, see Pierluigi Lanfranchi, L'Exagogé d'Ezéchiel le Tragique: Introduction, texte, traduction et commentaire, SVTP 21 (Leiden: Brill, 2006), 273-96.

67 On Moses's speeches in Josephus, Pere Villalba i Varneda, The Historical Method of Flavius Josephus, ALGHJ 19 (Leiden: Brill, 1986), 26. Spilsbury, Image, 97-8. On Josephus's use of speeches, notably in Vita and Bellum, Steve Mason, "Speech-making in Ancient Rhetoric, Josephus, and Acts: Messages and Playfulness,” Early Christianity 2 (2011): 445-67; 3 (2012): 147-71. 
I $\sigma \alpha \propto \eta \lambda) .{ }^{68}$ Had Josephus's source been like the text attested by 4Q22, the Masoretic Text, or even by the Syriac version, it would be more difficult to explain Josephus's omission of the elders of Israel. Thus, for the end of Exod 17:6 it seems more probable that Josephus used a text similar to that of the Greek Bible: the miracle occurred "in front of the children of Israel" as a whole, and not "in front of the elders" only. However, that does not necessarily mean that the biblical text used by him was in Greek. ${ }^{69}$

We have so far highlighted some of Josephus's trends in dealing with the Massah and Meribah tradition. However, what strikes most in Josephus's account of the water from the rock is that Josephus expands the biblical account, and describes the event as a miracle. Moses strikes the rock, which opens widely, letting abundant, clear water gush forth. The rock in Josephus "gapes open” (Ant. 3.37): the Greek verb is $\chi \alpha$ ív $\omega$, one of the terms that he uses for the opening of the earth that swallowed Corah and his followers (Ant. 4.48, 52). The Israelites are astonished at this unexpected occurrence, their thirst ceases at the sight; the water is delightful and sweet, and it appears as a gift of God. If we exclude the detail of the abundant water that is found in Num 20:11, these details are not in the account of Exodus and Numbers, although some echoes are found in the Psalms tradition. ${ }^{70}$ One cannot speak of a consistent trend of "rationalization" in Josephus's dealing with biblical miracle stories; ${ }^{71}$ however, some episodes of the Exodus account (Ant. 3.5-8 and 3.25) are undoubtedly expanded and explained in more "natural" terms. A few paragraphs before the Massah and Meribah episode, Josephus had explained the miracle of the quails of Exodus 16 by saying that the birds were very common in the Arabian Gulf; that they fell upon the Hebrews because they were exhausted from the flight, and because they fly very close to the ground (Ant. 3.25). In the same context of the wilderness, the episode of the bitter water of Marah of Exodus 15 is extensively elaborated by Josephus: according to the biblical text Moses simply threw a piece of wood into the water and it became sweet (Exod 15:23-25); in Josephus the water is sweetened by the

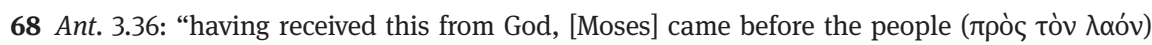
who were waiting and were looking expectantly from him. For they had, indeed, perceived him

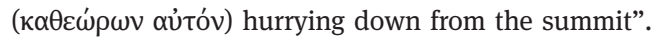

69 On the difficulty to determine Josephus's text, see also Spilsbury, "Exodus in Josephus," 466.

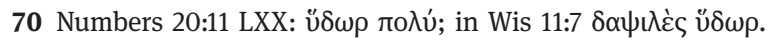

71 The view of Josephus's rationalization of miracles (see e.g., Feldman, Interpretation, 39, 55, 209 -14) has been challenged by Koskenniemi, Miracle-Workers, 228 - 80, followed more recently by Michael Avioz, “Josephus' Concept of Miracles," Zutot 9 (2012): 1-25. We agree with the general view of both authors; however, on the interpretation of some specific episodes, see note 72 below. 
synergetic action of Moses and the people (Ant. 3.5-8). ${ }^{72}$ Even in the episode of Corah's revolt, before stating that the earth opened wide and swallowed the rebels (Num 16:31-32), Josephus describes the phenomenon as an earthquake, giving a sort of natural explanation to the extraordinary event (Ant. 4.51); likewise, he tries to explain the supernatural fire of Numbers 16:35 that consumed Corah's followers (Ant. 4.55). Two natural reasons as to why the water issued forth in that way at Massah and Meribah are also provided by Philo's Vita Mosis 1.211. ${ }^{73}$ Now, why does Josephus choose to describe the episode of the water from the rock of

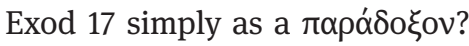

In a personal aside, appended as a conclusive statement of our episode, Josephus upholds his account by referring to an authoritative writing lying in the

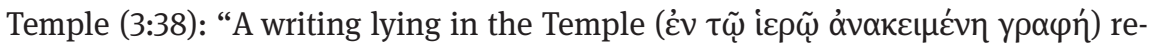
veals ( $\delta \eta \lambda$ ĩ) that God foretold to Moses that water would thus issue forth from the rock." With “God foretold to Moses” Josephus seems to refer to Exod 17:5-6, where God tells Moses what will occur. We shall leave the speculations on the nature of this writing, and on the impact of Josephus's statement on his audience for another place. ${ }^{74}$ Here, however, we shall clarify why Josephus not only does not explain the miracle, as he often does, but actually enhances the marvellous scene, claiming to remain faithful to a writing lying in the Temple. Certainly, the authority of the writing he appeals to would justify the description of the episode as a miracle in the eyes of his non-Jewish audience. Yet, there was no need to keep the miraculous story in these terms.

A first-century interpretation of the passage may shed light on Josephus's motivations. As early as the fifties of the Common Era, 1 Cor 10:4 attests the tra-

72 Avioz challenges Feldman's view that the episode of Marah is rationalized, in the sense of explained in natural terms. Whereas it is true that assigning the initiative for the action to Moses is not rationalizing the miracle, in the episode of Marah Josephus accentuates also the human co-operation: in this specific case, Josephus does not simply "expand the story to make it comprehensible to his readers" (Avioz, "Miracles," 18). Later on Avioz nuances his terms: while there is no solid tendency in Josephus to rationalize the accounts of miracles, "a partial rationalization” may occur (Avioz, "Miracles," 19). Avioz mainly targets Feldman's general argument for Josephus's "rationalization," that is apologetic, and the concept of "rationalization” itself (Avioz, "Miracles," 25).

73 Mos. 1.211: "it may be that the rock contained originally a spring and now had its artery clean severed, or perhaps that then for the first time a body of water collected in it through hidden channels was forced out by the impact" (Translation: Francis Henry Colson, trans., Philo: Volume VI, LCL [Cambridge: Harvard University Press, 1994]).

74 Part of this investigation has been published in Silvia Castelli, "Interventi personali nella Bibbia di Flavio Giuseppe: il caso di Ant. 3.38," in Tra politica e religione. I giudei nel mondo greco-romano. Studi in onore di Lucio Troiani, ed. Livia Capponi (Milano: Jouvence, 2019), 161-78. 
dition according to which the rock followed the Israelites in the desert. ${ }^{75}$ Probably in order to explain the doublet of the miracle of the water in Exodus and Numbers, the tradition developed into the idea of a rock (or a well) following the Israelites in the desert. ${ }^{76}$ That tradition is widely attested in targumic and rabbinic literature, ${ }^{77}$ but it may have been known already to Ezekiel the Tragedian, according to whom the twelve springs of Elim flow from a single rock. ${ }^{78}$ It is certainly reflected in the narrative midrash of Pseudo-Philo (LAB 10.7):

He [God] guided his people in the wilderness for forty years. He rained down for them bread from heaven and brought quails to them from the sea and brought forth $a$ well of water to follow them. ${ }^{79}$

751 Cor 10:4: ع̈лıvov yò they drank from the spiritual rock that followed them, and the rock was Christ” (NRSV). Joseph A. Fitzmyer, First Corinthians (New Haven: Yale University Press, 2008), 383-4; Gordon Fee, The First Epistle to the Corinthians, rev. ed., NICNT (Grand Rapids, MI: Eerdmans, 2014), 494-5. 76 See James Kugel, Traditions of the Bible: A Guide to the Bible as it Was at the Start of the Common Era (Cambridge: Harvard University Press, 1998), 620. Fitzmyer, First Corinthians, 382, argues that this tradition probably originated from an interpretation of Numbers 21, which narrates the march of the Israelites through the Moabite territory.

77 The Seder Olam (S. 'Olam Rab. 5) is sometimes quoted as attesting the tradition of the wandering rock, but it simply refers to the well given to the Israelites at Rephidim with no further specifications about a "travelling well". References to the travelling well are clearly found in t. Sukkah 3.11; Tg. Onq. and Tg. Ps.-J. Num 21:19-20; Num. Rab. 19:26; b. Ta‘an. 9a; b. Šabb. 35a.

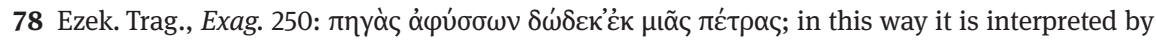
Howard Jacobson, The Exagogé of Ezekiel (Cambridge: Cambridge University Press, 1983), 154: "What may increase the likelihood of a connection between the Rabbis' wandering well and Ezekiel's Elim is that the well is occasionally described as a rock - or as being like a rock (e.g. Numbers Rabbah 1.2)"; Jacobson is followed by Koskenniemi, Miracle-Workers, 81. Lanfranchi, Exagogé, 281, mentions also the parallel of Euripides, Bacch.704-5, which makes the reference to Exod 17 less strong. The interpretation of Jacobson, however, is not certain: the fact that in Ezekiel the twelve springs flow from a single rock does not necessarily indicate that the rock was following the Israelites.

79 Populum autem suum deduxit in heremum, quadraginta annis pluit illis de celo panem, et ortigometram adduxit eis de mari, et puteum aque consequentis eduxit eis. The translation above is by Howard Jacobson, A Commentary on Pseudo-Philo's Liber Antiquitatum Biblicarum, 2 vols. (Leiden: Brill, 1996). Feldman has argued that Josephus probably knew Pseudo-Philo and certainly was acquainted with several traditions attested in it: Louis H. Feldman, "Prolegomenon to M.R. James," in The Biblical Antiquities of Philo: Now First Translated from the Old Latin Version, ed. Montague Rhodes James, 2nd ed. (New York: Ktav Publishing House, 1971), ix-clxix, points out 30 parallels between Josephus and Pseudo-Philo, but also 36 points of disagreement. Cf. Louis H. Feldman, Studies in Hellenistic Judaism (Leiden: Brill, 1996), 57-82. 
Undoubtedly, the tradition of the rock following the Israelites is attested in a Christian writing, that Josephus most probably did not know. But it is certainly possible that Josephus was acquainted with the Jewish tradition of the well following the Israelites, either directly through Pseudo-Philo - if we accept an early date of it - or through a common tradition ${ }^{80}$ - if we accept the later date of Howard Jacobson. ${ }^{81}$ We argue, therefore, that Josephus's editorial comment at the end of his account of Exod 17:1-7 addresses not only his non-Jewish audience, to justify the terms of his account of the miracle, but also a Jewish audience. In so doing, Josephus would aim at reaffirming the correct interpretation of the passage against alternative contemporary interpretations such as the tradition of the travelling rock or well attested in 1 Corinthians and Pseudo-Philo (and possibly, but less certainly, echoed already in Ezekiel the Tragedian).

\section{Conclusion}

In this article we have highlighted that the testing motif plays a key role in the reinterpretations of the Massah and Meribah episode in the Hebrew and the Greek Bible, and in its re-interpretation in the book of Judith.

Our survey of the Hebrew Bible passages renders six main results. First, it is apparent that there are three parties involved in the testing: God, the people of Israel and the people's leader and/or God's representative, and Moses (or Moses and Aaron). ${ }^{82}$ Second, a few passages seem to suggest that Moses was tested as well by God (Exod 17:1-7; Num 20:8-12; cf. Exod 15:22-26). Third, one passage focuses explicitly on the testing of Levi, who is associated with Moses through references to Massah and Meribah (Deut 33:8-11), and legitimates Levi's tribe's priestly activities on the basis of the outcome of the test at Massah and Meribah. Fourth, the relevant passages in Psalms (Ps 78:15-20, 40 -41, 56; 81:7; 95:8-11; 106:14, 32-33) imply the opposite view: they ignore the role of Moses in the testing, because God puts the people to the test or vice versa. Fifth, the view of

80 Vered Noam, “Did the Rabbis Know Josephus' Works?” Tarbiz 81 (2012), 367-95; Noam, “Lost Historical Traditions: Between Josephus and the Rabbis," in Sybils, Scriptures, and Scrolls: John Collins at Seventy, ed. Joel Baden, Hindy Najman, and Eibert Tigchelaar (Leiden: Brill, 2017), 991-1017.

81 In the French edition (Daniel J. Harrington and Jacques Cazeaux, Pseudo-Philon: Les Antiquités Bibliques, SC 229-230 [Paris: Cerf, 1976], 2:66-74), LAB is dated slightly before 70; Jacobson, Pseudo-Philo, 1:199-210, places the work in the early second century CE.

82 The passages in Psalms (Ps 78:15-20, 40 -41, 56; 106:14, 32-33) referring to testing are exceptional because they ignore the role of Moses. 
Psalms implies that the role of Moses (and Aaron) as leader of the people is interpreted in multiple and very different ways: this role is minimized in the Psalms and Ps 78 even states that God himself struck the rock at Horeb (78:20). Finally, the execution of the miracle is described in different ways, but the miracle itself remains unexplained.

The most important re-interpretations of the episode in the Septuagint concern the translations of Exod 17:1-7 (notably, several details at vv.4-6) and Deut 33:8-11. The latter passage interprets the motif of testing differently than the Masoretic Text by explicitly stating that the Israelites put Levi(-Moses) to the test; moreover, the Septuagint sets the blessing of Deut 33:8-11 in a messianic and eschatological framework.

The book of Judith (chapters 7-15) does not refer explicitly to the Massah and Meribah episode, but it seems to build on the episode as narrated in Exod 17 as well as on the blessing of Levi of Deut 33:8-11. First, the topic of the shortage of water echoes that of Exod 15 and Exod 17 in the wilderness. Second, the testing motif is central in Judith and more complex than in previous passages: on the one hand, the Bethulians as well as their leaders put God to the test; on the other hand, in Judith's interpretation the shortage of water is due to the fact that God is testing his people and its leaders. Third, Judith's plan seems to imply that she puts herself to the test as well, in the position of the alternative leader. Finally, Judith's prayers, as well as the blessing of Judith by the elders, build on the blessing of Levi by Moses in Deut 33:8-11, where Levi's passing the test legitimates his priestly role and authority.

Josephus's re-interpretation of the Massah and Meribah tradition is different from the other re-interpretations discussed in this contribution. Josephus downplays the testing motif, but highlights the role of Moses and the miracle itself. First, Josephus clearly prefers the account of Exodus rather than that of Numbers, which helps him to avoid the questionable portrait of Moses that is apparent from Num 20. The testing motif, that is so central in the biblical account of Exod 17 and Num 20, is altogether omitted in Josephus's account of the episode, yet it is clustered together with the motif of quarrelling in Josephus's expanded account of the oasis of Elim (Exod 15). Josephus's usual trend to make Moses appear more positive than in the biblical account, as well as his attempt to create variation in the narrative in relation to his account of Elim, may explain Josephus's choice to close the episode of Exod 17 not by mentioning the origin of the name "Massah and Meribah," but by adding a happy end: the Israelites show their admiration for their leader, who has been so highly honoured by God. Moses is portrayed as a proactive and sympathetic leader, not simply as an executor of God's instructions who is moved by fear for his own life. As for the Exodus's account specifically, Josephus clearly takes position in the conun- 
drum of the biblical location of the episode: he openly sets the miracle at Rephidim in line with Exodus 17:1, and not at Horeb, as implied by Exodus 17:6. The image of Moses performing the miracle in front of the Israelites as a whole (Ant. 3.36-37) is better explained with a text close to the Septuagint (Exod

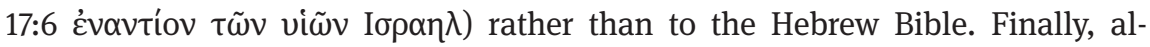
though Josephus mostly explains the biblical description of miracles in his wilderness narrative, in the case of the water from the rock he enhances the features

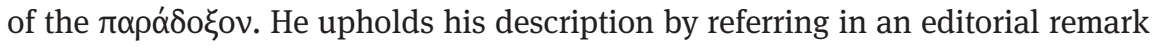
to the interpretation of a writing from the Temple. The authority of that writing would justify the description of the episode as a miracle in the eyes of Josephus's non-Jewish audience. But Josephus's editorial comment may also address a Jewish audience: in so doing, Josephus would reaffirm the correct interpretation of the passage against alternative contemporary interpretations such as the tradition of the travelling rock or well attested in 1 Corinthians 10:4 and PseudoPhilo, LAB 10.7, as well as in rabbinic literature.

\section{Bibliography}

Avioz, Michael. “Josephus' Concept of Miracles.” Zutot 9 (2012): 1-25.

Avioz, Michael. Josephus' Interpretation of the Book of Samuel. LSTS 86. New York: Bloomsbury, 2015.

Beyerle, Stefan. "Evidence of a Polymorphic Text: Towards The Text-History of Deuteronomy 33.” DSD 5 (1998): 215-32.

Beyerle, Stefan. Der Mosesegen in Deuteronomium. Berlin: De Gruyter, 1997.

Brooke, George J. "The Rewritten Law, Prophets, and Psalms: Issues for Understanding the Text of the Bible." Pages 31-40 in The Bible as Book: The Hebrew Bible and the Judaean Desert Discoveries. Edited by Edward D. Herbert and Emanuel Tov. London: British Library and Oak Knoll Press, 2002.

Castelli, Silvia. "Interventi personali nella Bibbia di Flavio Giuseppe: Il caso di Ant. 3.38." Pages 161-78 in Tra politica e religione. I guide nel mondo greco-romano. Studi in onore di Lucio Troiani. Edited by Livia Capponi. Milano: Jouvence, 2019.

Colson, Francis Henry, trans. Philo: Volume VI. LCL. Cambridge: Harvard University Press, 1994.

de Rossi, Giovanni Bernardo. Variae Lectiones Veteris Testamenti ... 3 vols. Parma: Bodoni, 1784.

Dogniez, Cécile, and Marguerite Harl. La Bible d'Alexandrie: Le Deuteronome. Paris: Cerf, 1992.

Duncan, Julie A. “New Readings for the ‘Blessing of Moses' from Qumran.” JBL 114 (1995): $273-90$.

Efthimiadis-Keith, Helen. "Genealogy, Retribution and Identity: Re-interpreting the Case of Suffering in the Book of Judith." OTE 27 (2014): 860-78. 
Elledge, Casey. "Rewriting the Sacred: Some problems of Textual Authority in Light of the Rewritten Scripture from Qumran." Pages 87-103 in Jewish and Christian Scripture: The Function of "Canonical" and "Non-canonical" Religious Texts. Edited by James Charlesworth and Lee M. Mc Donald. London: T\&T Clark, 2010.

Fee, Gordon. The First Epistle to the Corinthians. Rev. ed. NICNT. Grand Rapids, MI: Eerdmans, 2014.

Feldman, Louis H. “Josephus' Portrait of Moses,” JQR 82.1 (1991-1992): 285-328; 83.2 (1992): 7-50; 83.3 (1993): 301-30.

Feldman, Louis H. "Prolegomenon to M.R. James." Pages ix-clxix in The Biblical Antiquities of Philo: Now First Translated from the Old Latin Version. Edited by Montague Rhodes James. 2nd ed. New York: Ktav Publishing House, 1971.

Feldman, Louis H. Josephus's Interpretation of the Bible. Berkeley: University of California Press, 1998.

Feldman, Louis H. Judean Antiquities 1-4: Translation and Commentary. FJTC 3. Leiden: Brill, 2000.

Feldman, Louis H. Studies in Hellenistic Judaism. Leiden: Brill, 1996.

Fitzmyer, Joseph A. First Corinthians. New Haven: Yale University Press, 2008.

Fuller, Russell. "The Blessing of Levi in Deut 33, Mal 2 and Qumran." Pages 31-44 in Konsequente Traditionsgeschichte. Edited by Rüdiger Bartelmus, Thomas Krüger, and Helmut Utzschneider. Fribourg: Universitätsverlag; Göttingen: Vandenhoeck \& Ruprecht, 1993.

Garton, Roy E. Mirages in the Desert: The Tradition-historical Development of the Story of Massah-Meribah. BZAW 492. Berlin: De Gruyter, 2017.

Gera, Deborah Levine. Judith. CEJL. Berlin: De Gruyter, 2013.

Gerleman, Gillis. "נסה nsh pi. versuchen.” THAT 2: 69-71.

Harrington, Daniel J., and Jacques Cazeaux. Pseudo-Philon: Les Antiquités Bibliques. 2 vol. SC 229/230. Paris: Cerf, 1976.

Houtman, Cornelis. Exodus. HCOT 2. Kampen: Kok, 1996.

Jacob, Benno. Das Buch Exodus. Stuttgart: Calwer Verlag, 1997.

Jacobson, Howard. A Commentary on Pseudo-Philo's Liber Antiquitatum Biblicarum. 2 vols. Leiden and Boston, and Köln: Brill, 1996.

Jacobson, Howard. The Exagogé of Ezekiel. Cambridge, and New York: Cambridge University Press, 1983.

Kautzsch, Emil. Gesenius’ Hebrew Grammar. Oxford: Clarendon Press, 1982.

Kennicott, Benjamin. Vetus Testamentum Hebraicum, cum Variis Lectionibus ... 2 vols. Oxford: Clarendon Press, 1776.

Koskenniemi, Erkki. The Old Testament Miracle-Workers in Early Judaism. WUNT 206. Tübingen: Mohr Siebeck, 2005.

Kugel, James L. The Bible as it Was. Cambridge: Harvard University Press, 1999.

Kugel, James. Traditions of the Bible: A Guide to the Bible as it Was at the Start of the Common Era. Cambridge: Harvard University Press, 1998.

Lanfranchi, Pierluigi. L'Exagogé d'Ezéchiel le Tragique: Introduction, texte, traduction et commentaire. SVTP 21. Leiden: Brill, 2006.

Le Boulluec, Alain, and Pierre Sandevoir. La Bible d'Alexandrie: L'Exode. Paris: Cerf, 1989.

Lehming, Sigo. “Massa und Meriba." ZAW 73 (1961): 71-7. 
Licht, Jacob. Testing in the Hebrew Scriptures and in Post-Biblical Judaism. Jerusalem: Magness Press, 1973 [Hebrew].

Lust, Johan, Erik Eynikel, and Katrin Hauspie, eds. Greek-English Lexicon of the Septuagint. 2 vols. Stuttgart: Deutsche Bibelgesellschaft, 1996.

MacDonald, Nathan. "Anticipations of Horeb: Exodus 17 as Inner-Biblical commentary." Pages 7-19 in Studies on the Text and Versions of the Hebrew Bible in Honour of Robert Gordon. Edited by Geoffrey Khan and Diana Lipton. Leiden: Brill, 2012.

Mason, Steve. "Speech-making in Ancient Rhetoric, Josephus, and Acts: Messages and Playfulness.” Early Christianity 2 (2011): 445-67; 3 (2012): 147-71.

Merideth, Betsy. "Desire and Danger: The Drama of Betrayal in Judges and Judith.” Pages 63-78 in Anti-Covenant: Counter-Reading Women's Lives in the Hebrew Bible. Edited by Mieke Bal. JSOTSup 81. Sheffield: Almond Press, 1989.

Moore, Carey A. Judith. AB 40. Garden City, NY: Doubleday, 1985.

Nickelsburg, George W.E. "Stories of Biblical and Early Post-Biblical Times." Pages 33-87 in Jewish Writings of the Second Temple Period: Apocrypha, Pseudepigrapha, Qumran Sectarian Writings, Philo, Josephus. Edited by Michael Stone. CRINT II/2. Assen: Van Gorcum; Philadelphia: Fortress Press, 1984.

Noam, Vered. “Did the Rabbis Know Josephus' Works?” Tarbiz 81 (2012), 367-95 (Hebrew).

Noam, Vered. "Lost Historical Traditions: Between Josephus and the Rabbis." Pages 991-1017 in Sybils, Scriptures, and Scrolls: John Collins at Seventy. Edited by Joel Baden, Hindy Najman, and Eibert Tigchelaar. Leiden: Brill, 2017.

Oikonomos, Elias B. Peirasmoi en te Palaia Diatheke: Oroi, Keimena kai morphologike ereuna. Athens: Bibliotheke tes en Athenais Philekpaideutikes Etaireias, 1965 (Greek).

Propp, William. Exodus 1-18: A New Translation with Introduction and Commentary. New York: Doubleday, 1999.

Ruppert, Lothar. "Das Motiv der Versuchung in vordeuteronomischer Tradition.” VT 22 (1972): $55-63$.

Schmitz, Barbara, and Helmut Engel. Judit: Übersetzt und ausgelegt. HThKAT. Freiburg im Breisgau: Herder, 2014.

Schmitz, Barbara. "Gott als Figur in deuterokanonischer Literatur." Pages 217-37 in Gott als Figur: Narratologische Analysen biblischer Texte und ihrer Adaptionen. Edited by Ute E. Eisen and Ilse Müllner. HBS 82. Freiburg im Breisgau: Herder, 2016.

Seesemann, Heinrich A. L. "пвір

Skehan, Patrick W., Eugene C. Ulrich, and Judith E. Sanderson. Qumran Cave 4.IV: Palaeo-Hebrew and Greek Biblical Manuscripts. DJD 9. Oxford: Clarendon Press, 1992.

Spilsbury, Paul. "Exodus in Josephus." Pages 465-84 in The Book of Exodus: Composition, Reception and Interpretation. Edited by Thomas B. Dozeman, Craig A. Evans, and Joel N. Lohr. VTSup 164. Leiden: Brill, 2014.

Spilsbury, Paul. The Image of the Jew in Flavius Josephus' Paraphrase of the Bible. TSAJ 69. Tübingen: Mohr Siebeck, 1998.

Ulrich, Eugene C., Frank Moore Cross, Sidnie White Crawford, Julie Ann Duncan, Patrick W. Skehan, Emanuel Tov, and Julio Trebolle Barrera. Qumran Cave 4.IX: Deuteronomy, Joshua, Judges, Kings. DJD 14. Oxford: Clarendon Press, 1995.

van Henten, Jan Willem. "Judith as Alternative Leader: A Reading of Judith 7-13." Pages 224-52 in A Feminist Companion to Esther - Judith - Susanna. Edited by Athalya Brenner. Sheffield: Sheffield Academic Press, 1995. 
van Henten, Jan Willem. "Words and Deeds: Seduction and Power in Judith and Deathproof." Pages 226-41 in A Feminist Companion to Tobit and Judith. Edited by Athalya Brenner-Idan and Helen Efthimiadis-Keith. FBC Second Series. London: Bloomsbury T\&T Clark, 2015.

van Henten, Jan Willem. The Triangle of Testing in the Wilderness (forthcoming).

Villalba i Varneda, Pere. The Historical Method of Flavius Josephus. ALGHJ 19. Leiden: Brill, 1986.

Weinfeld, Moshe. Deuteronomy 1-11: A New Translation with Introduction and Commentary. New Haven: Yale University Press, 1991.

Wevers, John William. Notes on the Greek Text of Deuteronomy. SCS 39. Atlanta: Scholars Press, 1995.

White Crawford, Sidnie. Rewriting Scripture in Second Temple Time. Grand Rapids, MI: Eerdmans, 2008.

Zenger, Erich. Das Buch Judit. JSHRZ I.6. Gütersloh: Gütersloher Verlagshaus, 1981. 